\title{
BANK SAMPAH LONTAR MANDIRI : PEMBERDAYAAN IBU-IBU PKK KELURAHAN LONTAR KECAMATAN SAMBIKEREP
}

\author{
Mei Indrawati ${ }^{1}$, Hidayat ${ }^{2}$, Chamariyah $^{3}$ \\ ${ }^{1}$ Universitas Wijaya Putra \\ ${ }^{2}$ Universitas Wijaya Putra \\ ${ }^{3}$ Universitas Wijaya Putra
}

meiindrawati@uwp.ac.id, hidayat@uwp.ac.id,chamariyahs@yahoo.com

\begin{abstract}
Abstrak
Sampah / limbah rumah tangga di satu sisi merupakan masalah bagi perkotaan di Surabaya, namun jika sampah / limbah rumah tangga dimanfaatkan dapat mendatangkan nilai ekonomi berupa tambahan pendapatan/income bagi rumah tangga. Dalam rangka memanfaatkan sampah / limbah rumah tangga inilah, maka kegiatan ini dilaksanakan. Kegiatan ini dilaksanakan di RT 05 RW 02 Kelurahan Lontar Kecamatan Sambikerep Kota Surabaya.

Tujuan dilaksanakannya kegiatan ini adalah : 1) Peningkatan pendapatan rumah tangga; 2) Peningkatan jiwa wirausaha bagi ibu-ibu PKK di RT 05 RW 02 Kelurahan Lontar; dan 3) Penataan administrasi Bank Sampah Lontar Mandiri.

Kegiatan ini menggunakan dua metode yaitu metode pelatihan dan pendampingan. Metode pelatihan meliputi : 1) Pelatihan kewirausahaan; 2) Pelatihan tertib administrasi dan 3) Pelatihan pemasaran. Sedangkan metode pendampingan meliputi :1) Pendampingan penguatan jaringan kegiatan pemasaran dan 2) Pendampingan penguatan kelembagaan.

Hasil dari kegiatan ini adalah : 1) Terdapat tambahan pendapatan rumah tangga antara Rp. 50.000 sampai dengan Rp. 150.000 per bulan; 2) Munculnya jiwa wirausaha bagi ibu-ibu PKK di RT 05 RW 02 Kelurahan Lontar; dan 3) Tersusunnya dokumen-dokumen administrasi Bank Sampah Lontar Mandiri.
\end{abstract}

Kata Kunci : Pemberdayaan, Bank Sampah, pelatihan; pendampingan; kewirausahaan

\section{PENDAHULUAN}

Latar Belakang

Pertambahan penduduk dan perubahan pola konsumsi masyarakat menimbulkan bertambahnya volume, jenis, dan karakteristik sampah yang semakin beragam. Sehingga sampah merupakan bagian yang tidak bisa terpisahkan dari kehidupan manusia. Pengelolaan sampah rumah tangga yang belum optimal mengakibatkan dampak negatif, diantaranya adalah dampak terhadap kesehatan masyarakat dan lingkungan yang menjadi tidak sehat dan tidak bersih. Oleh karena itu sampah telah menjadi permasalahan nasional.

Surabaya dengan jumlah penduduk 3.07 juta jiwa, menyumbang sampah yang masuk ke TPA Benowo sebanyak 1600 ton per hari. Jadi pelibatan masyarakat dalam pengelolaan sampah secara mandiri harus ditingkatkan, namun upaya untuk mengedukasi masyarakat bukanlah hal yang ringan, dan tidak bisa dilakukan dalam waktu singkat (Dinas Komunikasi dan Informatika Provinsi Jawa Timur, 2019). Ide dan inisiatif yang sangat cerdas dari masyarakat dengan memunculkan Bank sampah merupakan salah satu solusi dan partisipasi dari masyarakat dalam menangani sampah yang telah menjadi permasalahan bersama selama beberapa dekade terakhir ini. Surabaya merupakan salah satu kota di Indonesia yang berhasil mengolah sampah dengan baik melalui bank sampah.

Bank Sampah merupakan kegiatan bersifat social egineering yang mengajarkan masyarakat untuk memilah sampah serta

$$
\text { Ekonomi, Sosial, dan Budaya } 1437
$$


menumbuhkan kesadaran masyarakat dalam pengeloaan sampah secara bijak dan pada gilirannya akan mengurangi sampah yang diangkut ke TPA (Tempat Pembuangan Akhir). Pembangunan bank sampah merupakan momentum awal membina kesadaran kolektif masyarakat untuk memulai memilah, mendaur ulang dan dan memanfaatkan sampah karena sampah mempunyai nilai jual yang cukup baik, sehingga pengelolaan sampah yang berwawasan lingkungan menjadi budaya baru Indonesia (Selomo, dkk., 2016).

Permasalahan sampah yang dihadapi oleh warga yang RT 5 RW 2 Kelurahan Lontar Kecamatan Sambikerep Kota Surabaya juga tidak berbeda dengan permasalahan yang dihadapi oleh Surabaya pada umumnya. Demi mengatasi masalah sampah ini, maka ada beberapa warga di RT ini yang berinisiatif untuk mendirikan bank sampah. Mereka sangat sadar bahwa sampah / limbah rumah tangga di satu sisi merupakan masalah bagi perkotaan di Surabaya, namun jika sampah / limbah rumah tangga dimanfaatkan dapat mendatangkan nilai ekonomi berupa tambahan pendapatan/income bagi rumah tangga. Mereka berusaha untuk memberdayakan diri sendiri dan sekaligus memupuk jiwa kewirausahaan. Dalam rangka memanfaatkan sampah / limbah rumah tangga inilah, maka kegiatan ini dilaksanakan.

Urgensi dan Rasionalisasi Kegiatan

Kegiatan pengabdian kepada masyarakat ini memiliki tingkat urgensi yang tinggi bagi keberlangsungan bank sampah dengan tertib administrasinya, dan memotivasi agar lebih berdaya serta menumbuhkan jiwa wirausaha bagi ibu-ibu PKK baik secara perseorangan maupun masyarakat pengelola bank sampah, khususnya Bank Sampah Lontar Mandiri yang berlokasi di RT 5 RW 2 Kelurahan Lontar Kecamatan Sambikerep Kota Surabaya.

Tujuan

Tujuan dilaksanakannya kegiatan ini adalah : 1) Peningkatan jiwa wirausaha bagi ibu-ibu PKK di RT 05 RW 02 Kelurahan Lontar; 2) Peningkatan pendapatan rumah tangga; dan 3)
Penataan administrasi Bank Sampah Lontar Mandiri.

\section{Rencana Penanganan Masalah}

Untuk menangani masalah yang ada di Bank Sampah Lontar Mandiri menggunakan dua metode yaitu metode pelatihan dan pendampingan.

Tinjauan Pustaka

Pemberdayaan Masyarakat

$$
\text { Menurut Mubarak }
$$

pemberdayaan masyarakat dapat diartikan sebagai upaya untuk memulihkan atau meningkatkan kemampuan suatu komunitas untuk mampu berbuat sesuai dengan harkat dan martabat mereka dalam melaksanakan hak-hak dan tanggung jawabnya selaku anggota masyarakat. Pemberdayaan merujuk pada kemampuan seseorang atau kelompok sehingga mereka memiliki kemampuan dalam memenuhi kebutuhan dasarnya, menjangkau sumber-sumber produktif yang memungkinkan mereka dapat meningkatkan pendapatannya dan memperoleh barang dan jasa yang mereka butuhkan serta berpartisipasi dalam proses pembangunan (Suharto, 2015).

Pemberdayaan memiliki tujuan melepaskan belenggu kemiskinan dan keterbelakangan serta memperkuat posisi lapisan masyarakat. Jadi dari sisi proses, pemberdayaan adalah serangkaian kegiatan untuk memperkuat keberdayaan kelompok lemah dalam masyarakat, termasuk individuindividu yang miskin. Sebagai tujuan pemberdayaan merujuk pada keadaan atau hasil yang ingin dicapai oleh sebuah perubahan sosial, yaitu masyarakat yang berdaya, mempunyai pengetahuan dan kemampuan dalam memenuhi kebutuhan hidupnya baik yang bersifat fisik, ekonomi maupun sosial, seperti memiliki kepercayaan diri, mampu menyampaikan aspirasi, mempunyai mata pencaharian, berpartisipasi dalam kegiatan sosial, dan mandiri dalam melaksanakan tugas-tugas kehidupannya (Sipahelut, 2010). Jadi pemberdayaan masyarakat adalah sebuah konsep pembangunan ekonomi yang merangkum nilai-nilai sosial. Pemberdayaan adalah sebuah usaha berkesinambungan untuk menempatkan 
masyarakat menjadi lebih proaktif dalam menentukan arah kemajuan dalam komunitasnya sendiri.

Pada hakikatnya pemberdayaan adalah sebuah berkesinambungan untuk menempatkan masyarakat lebih proaktif dalam menentukan arah kemajuan dalam komunitasnyan sendiri. Artinya program pemberdayaan tidak bisa hanya dilakukan dalam satu siklus saja dan berhenti pada satu tahapan tertentu, akan tetapi harus terus berkesinambungan dan kualitasnya terus meningkat dari satu tahapan ke tahapan berikutnya (Mubarak, 2010). Terdapat tujuh tahapan dalam siklus pemberdayaan masyarakat : (1) Keinginan dari masyarakat sendiri untuk berubah menjadi lebih baik; (2) Masyarakat diharapkan mampu melepaskan halangan-halangan atau faktor-faktor yang bersifat resistensi terhadap kemajuan dalam dirinya dan komunitasnya; (3) Masyarakat diharapkan sudah menerima kebebasan tambahan dan merasa memiliki tanggung jawab dalam dirinya dan komunitasnya; (4) Upaya untuk mengembangkan peran dan batas tanggung jawab yang lebih luas, dan memiliki minat dan motivasi untuk melakukan pekerjaan dengan lebih baik; (5) Hasil nyata dari pemberdayaan mulai terlihat, peningkatan rasa memiliki dan menghasilkan kinerja yang lebih baik; (6) Terjadi perubahan perilaku dan kesan terhadap dirinya; dan (7) Masyarakat yang telah berhasil memberdayakan dirinya, tertantang untuk menghasilkan kinerja yang lebih baik.

Kewirausahaan

$$
\text { Ananda dan Rafida (2016) }
$$
menyatakan bahwa wirausaha adalah kemampuan untuk menciptakan, mencari dan memanfaatkan peluang dalam menuju apa yang diinginkan sesuai dengan yang diidealkan. Steinhoff dan Burgess dalam Ananda dan Rafida (2016) mengatakan bahwa entrepreneur adalah orang yang mengorganisir, mengelola/menjalankan dan berani menanggung resiko untuk menciptakan usaha baru dan peluang berusaha. Jadi seorang entrepreneur adalah orang yang melihat adanya peluang kemudian menciptakan sebuah organisasi untuk memanfaatkan peluang tersebut. Entrepreneur adalah mereka yang bisa menciptakan kerja bagi orang lain dengan berswadaya. Drucker (1993) dalam Ananda dan Rafida (2016) menyatakan bahwa entrepreneur adalah orang yang memilikimkemampuan untuk menciptakan sesuatu yang baru, berbeda dari yang lain atau mampu menciptkan sesuatu yang berbeda dengan yang sudah ada sebelumnya.

Entrepreneurship (kewirausahaan) adalah proses seseorang atau sekelompok orang memikul resiko ekonomi untuk menciptakan organisasi baru yang akan mengeksploitasi teknologi baru atau proses yang inovatif yang menghasilkan nilai untuk orang lain. Zimmerer (2009) menjelaskan kewirausahaan sebagai suatu proses penerapan kreativitas dan inovasi dalam memecahkan persoalan dan menemukan peluang untuk memperbaiki kehidupan atau usaha. Wijatno (2009) kewirausahaan adalah hasil dari proses menerapkan kreativitas dan inovasi secara sistematis dan teratur terhadap kebutuhan dan peluang yang ada untuk memenuhi kebutuhan konsumen atau memecahkan masalah konsumen. Menurut Prawiro dalam Suryana (2009) kewirausahaan adalah suatu nilai yang diperlukan untuk memulai suatu usaha (startup phase) dan perkembangan usaha (venture growth). Sedangkan Siagian dan Asfahani dalam Ananda dan Rafida (2016) mendefinisikan bahwa kewirausahaan adalah semangat, perilaku dan kemampuan untuk memberikan tanggapan yang positif terhadap peluang memperoleh keuntungan untuk diri sendiri atau pelayanan yang lebih baik pada pelanggan/masyarakat, dengan selalu berusaha mencari dan melayani pelanggan lebih banyak dan lebih baik, serta lebih efisien, melalui keberanian mengambil resiko, kreativitas dan inovasi serta kemampuan manajemen menyedikan produk yang klebih bermanfaat dan menerapkan cara kerja. Jadi inti dari kewirausahaan adalah kemampuan untuk menciptakan sesuatu yang baru dan berbeda (create new and differrent) melalui aktivitas berfikir kreatif dan inovatif.

Dari hal-hal di atas dapat dipahami bahwa entrepreneur (wirausaha) adalah : 1) seseorang yang bebas dan memiliki kemampuan untuk hidup mandiri dalam menjalankan kegiatan usahanya atau bisnisnya 
atau hidupnya; 2) seseorang yang bebas merancang, menentukan pengelolaan dan mengendalikan usahanya; dan 2) seseorang yang terampil memanfaatkan peluang dalam mengembangkan usahanya dengan tujuan untuk meningkatkan kehidupannya.

\section{Sedangkan entrepreneurship} (kewirausahaan) dapat dipahami bahwa : 1) sikap jiwa dan kemampuan untuk menciptakan sesuatu yang baru yang sangat bernilai dan berguna bagi dirinya dan orang lain; 2) sikap mental dan jiwa yang selalu aktif atau kreatif dalam berusaha dalam rangka menciptakan pendapatan dalam kegiatan usahanya atau kiprahnya; 3) usaha menciptakan nilai tambah dengan jalan mengkombinasikan sumbersumber melalui cara-cara baru dan berbeda untuk memenangkan persaingan; dan 4) suatu proses dalam mengerjakan sesuatu yang baru (creative) dan sesuatu yang berbeda (inovative) yang bermanfaat bagi konsumen dan memberi nilai lebih.

\section{METODE}

Untuk menangani masalah yang ada di Bank Sampah Lontar Mandiri menggunakan dua metode yaitu metode pelatihan dan pendampingan. Metode pelatihan meliputi : 1) Pelatihan kewirausahaan dan 2) Pelatihan tertib administrasi. Sedangkan metode pendampingan meliputi : Pendampingan penguatan kelembagaan.

1) Metode Pelatihan

Pada metode pelatihan ini, diawali dengan diadakannya kegiatan penyuluhan tentang kewirausahaan kepada seluruh nasabah dan pengurus Bank Sampah Lontar Mandiri. Sedangkan penyuluhan tentang tertib adminsitrasi diberikan kepada para pengurusnya.

Setelah dilakukan penyuluhan, dilanjutkan dengan kegiatan simulasi.

2) Metode Pendampingan

Metode pendampingan dilakukan setelah dilakukannya kegiatan pelatihan. Kegiatan pendampingan ini meliputi pendampingan tertib administrasi, dimana pengurus Bank Sampah Lontar Mandiri menyusun berbagai macam buku yang diperlukan dalam administrasi Bank Sampah, diantaranya adalah : buku daftar presensi anggota setiap kali menimbang sampah, buku daftar penerimaan sampah dari nasabah, buku anggota nasabah bank sampah, buku agenda bank sampah, buku inventaris.

Adapun secara proses, langkah-langkah sistematis yang dilakukan dalam pelaksanaan kegiatan pengabdian kepada masyarakat ini adalah sebagai berikut :

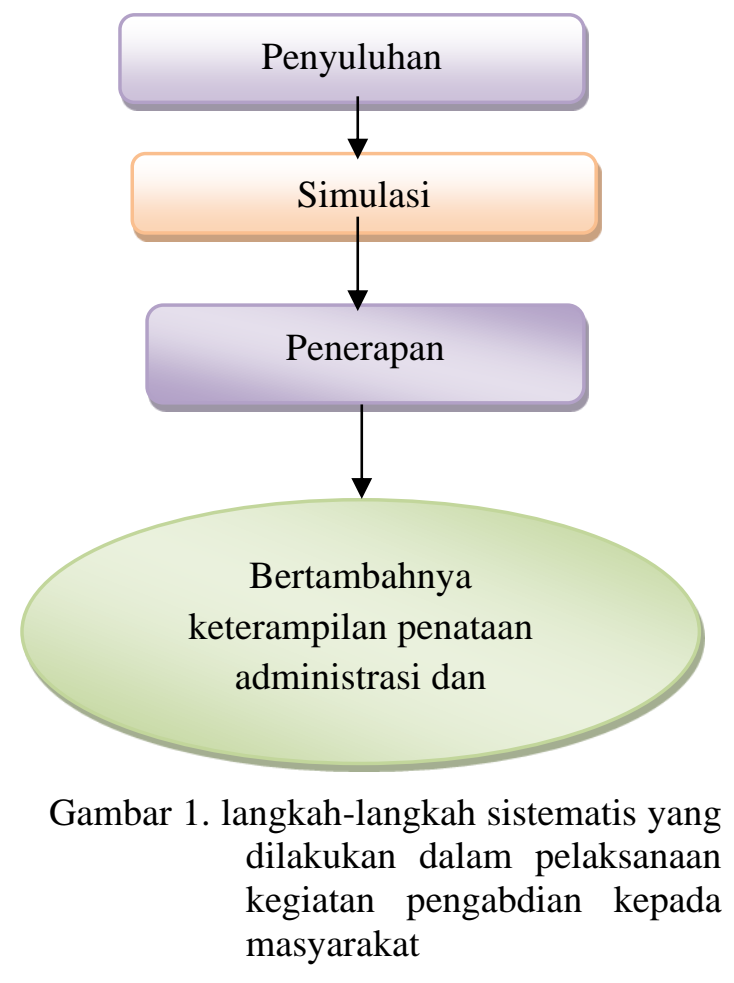

\section{HASIL DAN PEMBAHASAN}

1. Keberadaan Bank Sampah Lontar Mandiri. Bank sampah Lontar Mandiri didirikan pada tanggal 12 Maret 2012. Berlokasi di RT 5 RW 2 Kelurahan Lontar Kecamatan Sambikerep Kota Surabaya, dengan susunan pengurus sebagai berikut:

$\begin{array}{ll}\text { Penasehat } & \text { : Bapak H. Suyitno } \\ \text { Ketua } & : \text { Ibu Hartatik } \\ \text { Sekretaris } & : \text { Ibu Yulianingsih } \\ \text { Bendahara } & : \quad \text { Ibu Nunung }\end{array}$

Nurwidya

Sie Pemilah : Bapak Sugeng, Bapak Latif, Bapak Tinus dan Bapak Hartono 


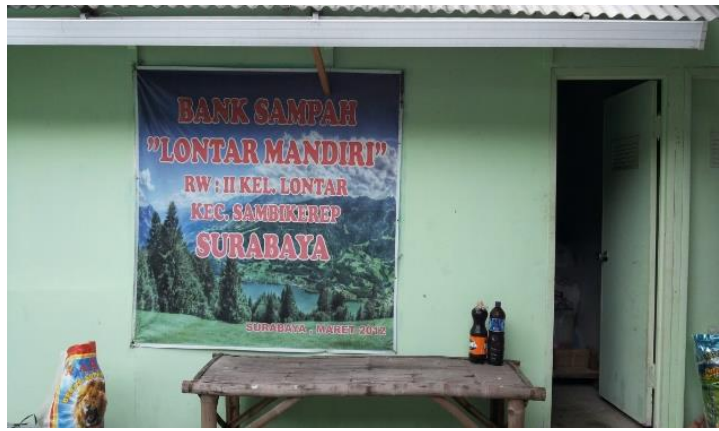

Gambar 2. Gudang Penyimpanan Bank Sampah Lontar Mandiri

Bank Sampah Lontar mandiri belum memiliki gudang penyimpan sampah. Saat ini gudang penyimpan sampah di tanah dan bangunan milik salah satu pengurus Bank Sampah Lontar Mandiri. Inventaris yang dimiliki saat ini berupa 1 (satu) timbangan electric dan 1 (satu) kendaraan roda 3 yang digunakan untuk mengambil sampah para nasabah yang dirasa terlalu jauh dan sampahnya cukup berat dan banyak. Hal ini merupakan salah satu bentuk pelayanan yang diberikan oleh Bank Sampah Lontar Mandiri.

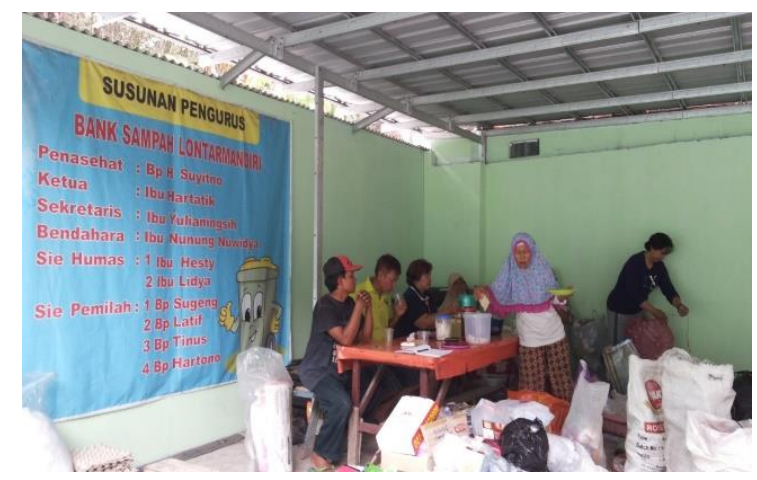

Gambar 3. Susunan Pengurus Bank Sampah Lontar Mandiri

Jumlah anggota Bank Sampah Lontar Mandiri saat ini sebanyak 90 orang nasabah. Alamat tempat tinggal anggota tersebar di RT 1, RT 2, RT 3, RT 5, dan RT 6 Kelurahan Lontar. Jumlah anggota sebanyak 90 orang untuk satu RW ini dirasa masih kurang. Oleh karena perlu upaya untuk meningkatkan jumlah nasabah.

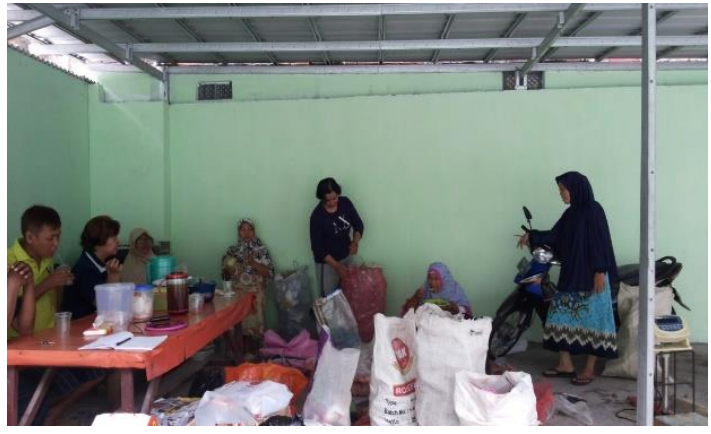

Gambar 4. Nasabah dan Pengurus Bank Sampah Lontar Mandiri

Waktu penerimaan / penimbangan sampah dilakukan setiap minggu pertama dan ketiga setiap bulan.

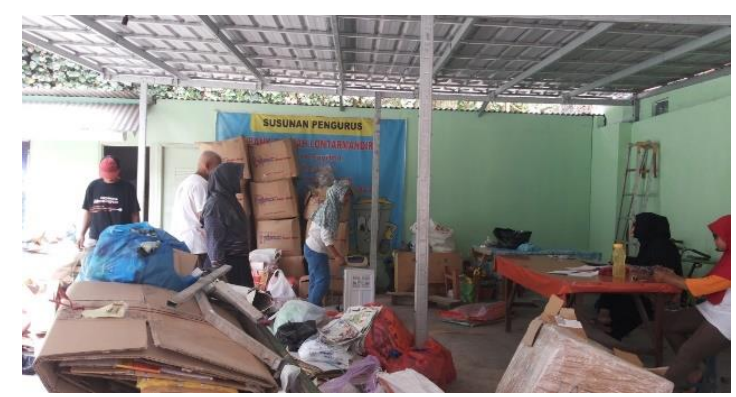

Gambar 5. Penimbangan Sampah Nasabah Oleh Pengurus Bank Sampah Lontar Mandiri

Sampah-sampah rumah tangga dari rumah penduduk dipilah menjadi beberapa kategori oleh pengurus yang mempunyai tugas memilah-milah sampah, dari sampah kemasan, plastik warna, plastik transparan, kertas, botol plastik dan kaleng. Umumnya sampah yang disetorkan berupa kardus, duplex/kertas karton. Hal ini dikarenakan belanja warga akan kebutuhan makanan yang dibungkus dengan kardus, kardus bekas rokok, dan kardus air mineral. Ada juga yang menyetorkan kertas HVS. Hal ini sesuai dengan hasil penelitian dari Rahman (2017).

Hasil pemilahan dijual ke pengepul yang secara berkala datang mengambil sampah dari para nasabah. Hasil penjualan sampah ke pengepul, sebanyak 95 persen untuk nasabah dan $5 \%$ untuk operasionalisasi kegiatan bank sampah. Pengurus akan mencatat jumlah dan jenis sampah yang disetorkan oleh nasabah. Tiap nasabah akan

Ekonomi, Sosial, dan Budaya 1441 
diberi buku anggota. Hasil penjualan disimpan dan akan dibagikan pada saat menjelang tahun ajaran baru (bukan hari raya Idul Fitri). Tetapi diperbolehkan juga bagi nasabah yang ingin dibayar pada saat mereka menimbang.

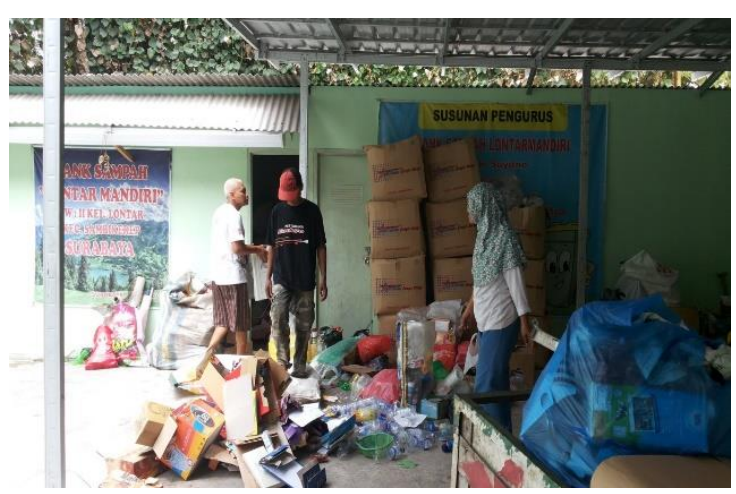

Gambar 6. Proses Pemilahan Sampah oleh Pengurus Bank Sampah Lontar Mandiri

2. Dengan adanya program penyuluhan dan pelatihan tentang kewirausahaan, maka motivasi ibu-ibu PKK untuk menjadi nasabah bank sampah semakin tinggi. Jiwa enterpreneur semakin tumbuh. Mereka semakin rasional bahwa sampah-sampah rumah tangga yang dianggap barang-barang bekas/sampah tersebut tidak ada harganya, tetapi setelah adanya penyuluhan, sekarang mereka sudah mulai tertib untuk memilah sampah anorganik mereka, karena dengan memilah sendiri mereka akan mendapat nilai yang lebih dibandingkan dengan jika sampah mereka dipilah oleh petugas. Kemudian pada jadwal yang telah ditentukan, mereka akan membawa ke bank sampah. Namun jika sampahnya terlalu banyak atau terlalu berat, maka petugas dari bank sampah akan datang mengambilnya.

Penyuluhan tertib administrasi bagi pengurus juga merubah kinerja mereka, karena dengan semakin tertibnya administrasi, semakin memudahkan pengurus untuk mengkoordinir penimbangan dan pemilahan (karena adanya buku presensi dan buku anggota), pembayaran (adanya buku penerimaan sampah) serta memudahkan dan mengingatkan mereka akan agenda kegiatan Bank Sampah Lontar Mandiri (buku agenda kegiatan) serta memudahkan pengecekan akan kebutuhan inventaris mereka (buku inventaris).

3. Dengan adanya pendampingan, maka jiwa wirausaha para nasabah semakin terasah, mereka semakin rajin untuk mengumpulkan, memilah dan menimbang sampahnya. Akan ada tambahan pendapatan bagi ibu-ibu PKK sebagai anggota/nasabah bank sampah. Karena ternyata tidak hanya kertas HVS dan kardus saja yang bisa dijual ke bank sampah, tetapi plastik, kaleng, logam, gelas/kaca/botol kaca, besi, minyak goreng bekas pakai juga bisa disetorkan ke bank sampah. Sehingga ibu-ibu PKK di RT 5 RW 2 Kelurahan Lontar Kecamatan Sambikerep Kota Surabaya, sudah diberdayakan dan menjadi wirausaha (entrepreneur). Hasil dari kegiatan ini adalah : terdapat tambahan pendapatan rumah tangga antara Rp. 50.000 sampai dengan Rp. 150.000 per bulan.

Sisi lain menjadi nasabah bank sampah adalah rumah mereka menjadi terang dan asri karena tidak ada lagi timbunan barangbarang bekas ataupun plastik sertas kardus yang menumpuk.

4. Kegiatan pendampingan membuat pengurus Bank Sampah Lontar Mandiri semakin terampil dalam mengelola/mengkoordinir para nasabahnya karena tersedianya bukubuku yang dibutuhkan dalam proses pengelolaan bank sampah. (tersusunnya dokumen-dokumen administrasi Bank Sampah Lontar Mandiri).

\section{KESIMPULAN}

1. Untuk menangani masalah yang ada di Bank Sampah Lontar Mandiri menggunakan dua metode yaitu metode pelatihan dan pendampingan. (a) Metode Pelatihan, meliputi : kegiatan penyuluhan tentang kewirausahaan kepada seluruh nasabah dan pengurus Bank Sampah Lontar Mandiri. Sedangkan penyuluhan tentang 
tertib adminsitrasi diberikan kepada para pengurus Bank Sampah Lontar Mandiri. Setelah dilakukan penyuluhan, dilanjutkan dengan kegiatan simulasi. (b) Metode Pendampingan, meliputi : pendampingan tertib administrasi, dimana pengurus Bank Sampah Lontar Mandiri menyusun berbagai macam buku yang diperlukan dalam administrasi bank sampah.

2. Dengan adanya program penyuluhan, pelatihan dan pendampingan tentang kewirausahaan, maka motivasi ibu-ibu PKK untuk menjadi nasabah bank sampah semakin tinggi. Jiwa enterpreneur semakin tumbuh, mereka semakin rajin untuk mengumpulkan, memilah dan menimbang sampahnya.

3. Penyuluhan dan pendampingan tertib administrasi bagi pengurus tersusun : buku presensi, buku anggota, buku penerimaan sampah, buku inventaris, buku agenda.

4. Terdapat tambahan pendapatan bagi ibu-ibu PKK sebagai anggota/nasabah bank sampah. Hasil dari kegiatan ini adalah : terdapat tambahan pendapatan rumah tangga antara Rp. 50.000 sampai dengan Rp. 150.000 per bulan;

\section{SARAN}

1. Bagi nasabah bank sampah. Berbekal pengalaman sebagai nasabah bank sampah, maka perlu untuk selalu mengasah jiwa kewirausahaan ibu-ibu PKK. Sehingga ketika ada peluang di depan mereka, hendaknya peluang tersebut ditangkap.

2. Bagi pengurus bank sampah perlu selalu meningkatkan kemampuan dan melanjutkan memotivasi para nasabah serta meningkatkan pelayanan.

3. Bagi instansi terkait, perlu mengadakan pembinaan seluruh masyarakat sehingga masyarakat semakin berdaya.
Ananda, Rusydi dan Tien Rafida (2016). Pengantar Kewirausahaan : Rekayasa Akademik Melahirkan Enterpreneurship. Medan : Perdana Publishing.

Dinas Komunikasi dan Informatika Propinsi Jawa Timur (2019). Majalah Potensi Jawa Timur Edisi 97

Mubarak, Z. (2010). Evaluasi Pemberdayaan Masyarakat Ditinjau Dari Proses Pengembangan Kapasitas Pada Program PNPM Mandiri Perkotaan di Desa Sastrodirjan Kabupaten Pekalongan. Tesis. Program Studi Magister Teknik Pemberdayaan Wilayah dan Kota. Semarang : Undip.

Sipahelut, Michel (2010). Analisis Pemberdayaan Masyarakat Nelayan di Kecamatan Tobelo kabupaten Halmahera Utara. Tesis. Bogor : IPB.

Shucksmith, Mark. (2013). Future Direction in Rural Development. England : Carnegie UK Trust.

Suharto, E. (2015). Membangun Masyarakat Memberdayakan Rakyat : Kajian Strategi Pembangunan Kesejahteraan Sosial dan Pekerjaan Sosial. Bandung : PT Refika Aditama.

Suryana (2009). Kewirausahaan : Pedoman Praktis, Kiat dan Proses Menuju Sukses. Jakarta : Salemba Empat.

Rahman, Reksa Pambudi (2017). Pengaruh Keberadaan Bank Sampah Terhadap Reduksi Produk Sampah di Surakarta. Tesis. Surakarta : Universitas Muhamadiyah Surakarta.

Wijatno (2009). Pengantar Entrepreurship. Jakarta : Grasindo

Zimmerer, T.W., Scarborough, N.M dan Wilson, D. (2009). Essential of Entrepreneurship and Small Business Management. New Jersey : Pearson.

\section{REFERENSI}


